\title{
Ciências Sociais: na ótica do intelectual militante
}

\section{FLORESTAN FERNANDES}

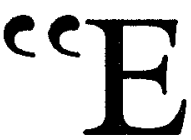

u nunca teria sido o sociólogo em que me converti sem o meu passado e sem a socialização pré e extra-escolar que recebi através das duras liçóes da vida. Para o bem e para o mal - sem invocar-se a questáo do ressentimento, que a crítica conservadora lançou contra mim - a minha formação acadêmica superpôs-se a uma formaçăo humana que ela não conseguiu distorcer nem esterilizar. Portanto, ainda que isso pareça pouco ortodoxo e antiintelectualista, afirmo que iniciei a minha aprendizagem sociológica aos seis anos, quando precisei ganhar a vida como se fosse um adulto e penetrei, pelas vias da experiência concreta, no conhecimento do que é a convipencia bumana e a sociedade em uma cidade na qual não prevalecia a ordem das bicadas, mas a relafáo de presa, pela qual o homem se alimentapa do homem, do mesmo modo que o tubaráo come a sardinha ou o gavião devora os animais de pequeno porte. A criança estava perdida nesse mundo hostil e tinha de voltar-se para dentro de si mesma para procurar nas técnicas do corpo e nos ardis dos fracos os meios de autodefesa para a sobrevivência. Eu não estava sozinho. Havia a minha mãe. Porém a soma de duas fraquezas não compóe uma força. Éramos varridos pela tempestade da vida e o que nos salvou foi o nosso orgulbo selpagem, que deitava raízes na concepção agreste do mundo rústico, imperante nas pequenas aldeias do norte de Portugal, onde as pessoas se mediam com o lobo e se defendiam a pau do animal ou de outro ser humano.

Há pouco interesse em descrever a variedade de ocupaçóes a que precisei dedicar-me ou as venturas e desventuras que pontilharam uma infância e uma adolescência tão marcadas pela necessidade de ganhar a vida, de buscar no trabalho - por vezes humilhante e degradante - um

\footnotetext{
A autobiografia intelectual de Florestan Fernandes pareceu à Editoria a sondagem mais funda que já se fez no sentido de compreender os fatos e os valores que marcaram a fase de solidificação dos cursos de Ciências Sociais na antiga Faculdade de Filosofia, Ciências e Letras. Dela transcrevemos alguns passos, mas convidamos o leitor a conhecé-la na íntegra. O texto foi extraído de: Florestan Fernandes - A Sociologia no Brasil, 2 ed., Petrópolis, Vozes, 1980, p. 142-179.
} 
instrumento de relação com os outros e de pressáo sublimadora. Fazendo o que me via forçado a fazer também era compelido a uma constiante busca para vencer uma condiçáo $\mathrm{em}$ que o lumpen-proletdrio (e não operário) definia os limites ou as fronteiras do que não era gente. Antes de estudar esse processo na pesquisa sobre o negro, vivi-o em todos os matizes e magnitudes. A fronteira que me era negada também era conhecida pela experiência concreta. $\mathrm{Na}$ casa da minha madrinha Hermínia Bresser de Lima, onde vivi durante uma parte da infância, ou ocasionalmente ia passar alguns dias; e na casa de outros patróes de minha mãe, entrei em contato com o que era ser gente e viver como gente. Além disso, através das várias ocupaçóes, morei na casa de empregadores - uma família negra, outra italiana e, parcialmente, uma familia sírio-libanesa. Em suma, do tradicional ao moderno, do nacional no estrangeiro, dei-me conta de quăo grande e complexo era o mundo, e que nada me forçava a encerrar-me no confinamento dos poróes, dos cortiços e dos quartos de aluguel em que morava com a minha máe. Por fim, a mobilidade imposta pelos empregos da minha mãe ou pela elevação dos aluguéis expôs-me a conhecer vários bairros de São Paulo e vários tipos de vizinhança. Se tinha pouco tempo para aproveitar a infância, nem por isso deixava de sofrer o impacto humano da vida nas trocinhas e de ter résteas de luz que vinham pela amizade que se forma através do companbeirismo (nos grupos de folguedos, de amigos de vizinhança, dos colegas que se dedicavam ao mesmo mister, como meninos de rua, engraxates, entregadores de carne, biscateiros, aprendizes de alfaiate e por aí a fora). $O$ caráter humano chegou-me por essas frestas, pelas quais descobri que o grande homem não é o que se impóe aos outros de cima para baixo ou através da história; ́́ o homem que estende a mão aos semelhantes e engole a própria amargura para compartilhar a sua condiçáo humana com os outros, dando-se a si próprio, como fariam os meus Tupinambá. Os que não têm nada que dividir repartem com os outros as suas pessoas - o ponto de partida e de chegada da filosofia de - folk' dentro da qual organizei a minha primeira forma de sabedoria sobre o homem, a vida e o mundo.

Essa filosofia de folk constitúa a cultura dentro da qual me movia, que só era suplementada pelos conhecimentos práticos requeridos pelos trabalhos que exercesse, todos muito rudimentares e de escasso valor técnico ou económico. Ela existia nas famílias tradicionais ou ricas, com que interagia marginal ou centralmente; mas era entre os pobres que ela imperava, tendo na vida dos bairros o seu suporte social. Assim, no convivio com os meninos da minha idade, com os companheiros de trabalho, mais novos ou mais velhos, e com as pessoas que faziam parte da vizinhança - e mais especialmente dentro de casa ou no convívio 
com os meus tios e avós, que moravam em Bragança e com os quais eu passava, vez ou outra, algum tempo - tornei-me típico morador pobre da cidade da década de 20 , que só era urbano pela localizaçáo espacial e pela relaçáo tangencial com o sistema de trabalho. Todos éramos rústicos e desenraizados, mesmo os que procediam do interior do estado de Săo Paulo, e todos estávamos aprendendo a viver na cidade, mesmo os que, como eu, nasceram dentro de seus marcos e dos seus muros. $O$ código de honra, a mentalidade, a noção de dever e de lealdade, o imperativo da solidariedade, até mesmo a sobranceria irredutível dos que estão por baixo não provinham da civilizafão - como gostam de dizer os antropólogos - nem do cosmos urbano ou da religião católica. Tudo aquilo fazia parte do que, mais tarde, aprendi ser a cultura do inculto e que a cidade ainda não destruíra. Ao contrário, à medida que as famílias ricas de deslocavam e deixavam seus sobrados para os pobres, ao se converterem em cortiços estes serviam como redutos a esta cultura (e também à variedade que ela assumia, graças às diversas origens nacionais, étnicas e raciais da populaçáo pobre e dependente). Mesmo quando a família rica alugava os porōes, essa realidade não se alterava. Portanto, várias cidades coexistiam lado a lado, dentro do mesmo espaço urbano, que não impunha qualquer idade cultural, mas harmonizava, horizontalmente, os contrários que se toleravam sem se comunicarem. Os que não eram gente ou que formavam a gentinba, apinhando-se nos interstícios, nos espaços vazios e zonas de transição, ou nos medonhos cortiços-gigantes - nos quais nunca cheguei a morar - não se urbanizapam, em termos de estilo de vida. Encontravam dentro da cidade um nicho no qual mantinham suas pequenas cidadelas culturais e seus diferentes padróes de rusticidade. Italianos, portugueses, espanhóis, gente do interior e o imenso rol dos pobres não escondiam a sua humanidade.

\section{(...)}

A minha socialização plebéia poderia ser mais rica. Porém, o submundo dentro do qual circulava, de engraxates, entregadores de carne, aprendizes de barbeiro ou de alfaiates, balconistas de padaria, copeiros, garçons, ajudantes de cozinheiro etc., fechava-se dentro de um círculo pobre. Os seus componentes náo acompanhavam com ardor os conflitos operários e com frequiência formavam a própria opinião através das pessoas a que serviam ou de jornais sensacionalistas. Uma criança ou um adolescente, dentro desse submundo, já faz muito quando enfrenta a pressáo negativa contra a curiosidade intelectual. Quando decidi fazer o curso de madureza, por exemplo, enfrentei a resistência rústica de minha mãe, que achava que eu iria ficar com vergonba dela, se estudasse; muito pior era a incompreensão e a chacota dos colegas, que ridicularizavam minha propensáo pelas leituras e meu apego aos livros dizendo que eu 
ia acabar com o miolo mole, de tanto ler; praticamente me incitavam a não deixar de ser como eles e a cultivar a ignorância como uma virtude ou a servidáo como um estado natural do homem. Nos bares e restaurantes em que trabalhei, por exemplo, nunca recebi um apoio ou um conselho construtivo de qualquer colega, da minha idade ou mais velho, embora entre os fregueses encontrasse simpatia, quem me desse ou emprestasse livros, e até apoio prático para ir mais longe. Se aprendi com aqueles homens de minhas velhas ocupaçóes, năo foi para mudar de ofício ou de vida. É que, entre eles, encontrei pessoas de valor, que enfrentavam as agruras da vida com serenidade e tinham o seu padrão de humanidade: sabiam ser homens e, nesse plano, eram mestres incomparáveis, com toda a sua rusticidade, depreciaçáo da cultura letrada e incompreensáo diante dos próprios interesses e necessidades. Foi deles que recebi a segunda capa de socialização, que se superpôs à anterior, pela qual descobri que a medida do bomem náo é dada pela ocupação, pela riqueza e pelo saber, mas pelo seu caráter, uma palavra que significava, para eles, pura e simplesmente, sofrer as bumilhacóes da vida sem degradar-se.

O toque final dessa preparaçáo sui generis foi dado pelo curso de madureza. Enquanto trabalhava no Bar Bidu, na rua Líbero Badaró, instalou-se no sobrado vizinho o Ginásio Riachuelo. Os professores iam ao bar tomar lanche, depois das aulas. Eu sempre ficava atento aos fregueses com os quais podia aprender alguma coisa. Cultivei as relaçóes com alguns dos professores - os mais comunicativos e assíduos - e obtive uma concessão, através do professor Jair de Azevedo Ribeiro de fazer os estudos sob pagamento reduzido. Graças a Manoel Lopes de Oliveira Neto, um dos fregueses de que me tornara amigo, arranjei outro emprego (como entregador de amostras do Laboratório Novoterápica); e graças ao apoio de Ivana e José de Castro Mano Preto, ligados à minha falecida madrinha, um pequeno auxílio marginal (que, mais tarde, se tornou de cama e comida permanentes), o problema do estudo ficou reduzido à expressão mais simples. Sair do bar e ter uma nova oportunidade, naquela época (1937), era algo notável. Os preconceitos contra esse tipo de gentejatingiam tais proporçóes que, nem com o apoio de Clara Augusta Bresser, irmã de minha madrinha, jamais logrei outra espécie de emprego. O mínimo que se pensava, sobre aquele tipo de gente, é que éramos ladróes ou imprestapeis!... O lumpen-proletário era, pois, a principal vítima de sua condiçăo serviçal e de sua vassalagem à ordem estabelecida. Vínhamos, na minha arquitetura mental daquela época, logo abaixo dos gatunos profissionais e dos vagabundos, das prostitutas e dos soldados da Força Pública. $O$ círculo de ferro fora rompido e, com o novo emprego, poderia manter minha mãe e pagar os 
estudos. A experiência concreta, por sua vez, não me fora inútil. $\mathrm{Na}$ pesquisa com Bastide, sobre relaçóes raciais em São Paulo, eu saberia dizer porque a incapacidade de obter uma posiçáo no sistema ocupacional da cidade pesara táo negativamente na história do meio negro na longa e penosa transiçăo do trabalho escravo para o trabalho livre.

\section{(...)}

Depois de ingressar na Universidade de Sáo Paulo não poderia continuar na Novoterápica, na qual precisaria trabalhar o dia todo. Por isso e outros motivos, já antes de terminar o curso de madureza me transferira para outras firmas, primeiro como empregado, mais tarde como vendedor à comissáo, nas quais operava, na cidade ou em municípios vizinhos, com artigos dentários. Depois, como eram grandes os encargos financeiros, comecei a trabalhar como propagandista em um laboratório, sediado no Rio de Janeiro, que produzia o Iodobisman e o Tropholipan, dois produtos de boa aceitação. Contava com uma remuneraçáo razoável, dispunha de mais tempo para freqüentar as aulas e estudar do que a firma empregadora poderia desconfiar e travei contato com o setor médico. Assim, das profissóes liberais fiquei conhecendo vários problemas com que se defrontavam os dentistas e os médicos e adquiri uma visão bem realista do que ia pelo setor pobre e dependente da populaçăo, em matéria de assistência dentária, médica e hospitalar. $O$ que importa, nesta passagem, é esclarecer que tinha um meio de manutenção e que poderia candidatar-me ao ensino superior, desde que escolhesse cursos de meio período. Por volta do início da década de quarenta não existiam cursos noturnos na USP; o meu campo de escolha ficava, pois, restrito à Faculdade de Direito e a alguns cursos da Faculdade de Filosofia, Ciências e Letras. Pretendia fazer, não me lembro por que se é que cheguei a saber - o curso de engenharia química, na Politécnica. Contudo, teria de ser aluno em tempo integral, o que me era impossível, pois tinha de manter a casa. A escolha das Ciências Sociais e Políticas correu por conta das oportunidades que coincidiam com os meus interesses intelectuais mais profundos. No caso, a escolba de uma profissáo quase não contou. Queria ser professor e poderia atingir esse objetivo através de vários cursos. $O$ meu vago socialismo levou-me a pensar que poderia conciliar as duas coisas, a necessidade de ter uma profissão e o anseio reformista de modificar a sociedade, cuja natureza eu não conhecia bem, mas me impulsionava na escolha das alternativas. Decidi-me pela secção de ciências sociais da Faculdade de Filosofia, Ciências e Letras. Esta herdava um bicho da cidade, em processo de desabrochamento intelectual e da descoberta de si mesmo. Seguindo a ótica atual, alguém poderia escrever: o lumpen-proletariado chega à Universidade de São Paulo. Todavia, não era o lumpen-proletariado que che- 
gava lá; era eu, o filho de uma ex-lavadeira, que não diria para a cidade de São Paulo agora nós, como um célebre personagem de Balzac. Eu levava comigo intençóes puras, $o$ ardor de aprender $e$, quem sabe, de tornar-me um professor de escola secundária.

A minha bagagem intelectual era produto do estranho cruzamento de um autodidatismo forçado com a curta aprendizagem compacta, realizada através do Riacbuelo (1). Graças a uma regalia instituída pelo artigo 100 dos cursos de madureza, eu podia tanto candidatar-me aos exames de seleção para o pré, subordinado à Faculdade de Filosofia, Ciências e Letras, quanto tentar os exames de habilitaçáo para a secção de ciências sociais e políticas. Na primeira hipótese, teria feito cinco anos em três; na segunda, sete anos em três. Embora inseguro, a conselho dos amigos empreendi as duas coisas simultaneamente; e obtive aprovação em ambos os casos. Isso significava: que eu anulara a desvantagem do atraso com que iniciara os meus estudos secundários, mesmo sem completar o primário; e que, pelos critérios vigentes, minha capacidade potencial era, pelo menos, comparável à dos colegas que haviam seguido o percurso normal. Na verdade, tanto eu quanto eles estávamos bem longe das exigências ou dos requisitos do ensino que iríamos enfrentar.

As falhas de formação e de informação eram imensas, por assim dizer enciclopédicas, e claramente insanáveis. Os mestres estrangeiros, que davam suas aulas na própria língua, não tomavam tais deficiências em consideração e procediam como se nós dispuséssemos de uma base intelectual equivalente à que se poderia obter através do ensino médio francês, alemão ou italiano. Os cursos eram monográficos - só o professor Hugon, que me lembre, ficava no petit $a$, petit $b$, do ensino básico, e era, por isso, ridicularizado em público pelo professor Maugué. Os professores assistentes acompanhavam a toada, movendo uma guerra sem quartel aos manuais e ao ensino geral. Pela organizaçáo dos cursos, essa seria a função do pré, onde nós deveríamos adquirir o conhecimento básico. Os candidatos às ciências sociais, por exemplo, faziam um exame escrito e um exame oral de sociologia (na argüiçáo oral, diante dos dois Bastides e de outro professor do qual náo me lembro, coubeme discutir um trecho de $D e$ la division du trapail social ). Mas todos sabíamos que o pré náo cumpria tal função e que o carro caminhava adiante dos dois, esmagando os estudantes. $O$ que nos impunha uma paradoxal saída: o recurso a um autodidatismo intensivo, às vezes supervisionado e orientado pelas cadeiras! O salto no escuro era a regra; o jogo, no entanto, era limpo, embora o desafio fosse tremendo. Só para dar um exemplo: o meu trabalho de aproveitamento com o professor Roger Bastide, no primeiro semestre de 1941, versava sobre a crise da explicaçá causal na sociologia. Reuni como me foi possível a bibliografia 
acessível na Biblioteca Municipal e na Biblioteca Central da Faculdade. Tirei nota quatro e meio, com um comentário piedoso do professor: o que ele esperava era uma dissertação, não uma reportagem. Essa experiência ensinou-me que ou deveria desistir, ou submeter-me a uma disciplina monástica de trabalho. Optei pela segunda solução e, aos poucos, ganhei maior elasticidade intelectual. A partir do fim do segundo ano e no terceiro ano tinha condições para competir com qualquer colega, de tirar proveito dessa sui generis montagem pedagógica e de responder às exigências da situação como um aluno aplicado ou talentoso. Em suma, malgrado as minhas origens, logrei vencer as barreiras intelectuais e ter exito como e enquanto estudante.

A partir desta etapa, declina a importância da socialização pelo trabalho, ligada às atividades práticas que exercia para ganhar a vida (as quais foram mantidas até 1947, mais de dois anos após minha contrataçáo como assistente de cadeira de Sociologia II da Faculdade de Filosofia). Não é que o contato com os dentistas, os médicos, as enfermeiras e alguns colegas que se tornaram amigos mais ou menos íntimos fossem irrelevantes, do ponto de vista do enriquecimento de minha pessoa ou da descoberta de novos mundos, que antes se ocultavam à minha percepçáo. Ao contrário, eles tiveram enorme significação e, inclusive, me ajudaram a libertar-me de velhos complexos inevitáveis e a adquirir maior independência na concepçáo de meus papéis sociais, de minhas possibilidades humanas e, principalmente, de uma ingenuidade tosca, incompatível com a cidade como estilo de vida. A questáo é que aquelas atividades práticas ficaram excêntricas ao que passou a ser, de modo absorvente, o meu alvo central. Elas eram um mero instrumento de manutenção, em termos imediatos, para atingir outro fim, a largo prazo. Aquele não era o' meu' mundo. Eu me descobrira e, ao mesmo tempo, sentia crescer dentro de mim uma vocação adormecida, que me dava forças e argúcia para aceitar o desafio de tornar-me um professor e um intelectual. De princípio, as coisas não possuíam muita clareza para mim. Mas já no segundo ano do curso eu sabia muito bem o que pretendia ser e me concentrava na aprendizagem do oficio - portanto, não me comparava ao bebê, que começa a engatinhar e a falar, porém ao aprendiz, que transforma o mestre-artesão em um modelo provisório. A cultura dos meus mestres estrangeiros me intimidava. Eu pensava que jamais conseguiria igualá-los. $O$ padrão era demasiado alto para as nossas potencialidades provincianas - para o que o ambiente poderia suportar - e especialmente para mim, com a minha precária bagagem intelectual $\mathrm{e}$ as dificuldades materiais com que me defrontava, as quais roubavam grande parte do meu tempo e das minhas energias do que gostaria de fazer. Contudo, como me propunha a ser um professor de nível médio, as frustraçóes e 
os obstáculos não interferiam no meu rendimento possível. $O$ desafio era trabalhado psicologicamente $e$, na verdade, reduzido à sua expressão mais simples: as exigências diretas das aulas, das provas e dos trabalhos de aproveitamento. Com isso, empobrecia o meu horizonte intelectual e humano. No entanto, não poderia sobrepujar-me e resolver os meus problemas concretos sem essa redução simplificadora, que se corrigiu por si própria, à medida em que progredi como estudante e adquiri uma nova estatura psicológica. Em suma, o Vicente que eu fora estava finalmente morrendo e nascia em seu lugar, de forma assustadora para mim, o Florestan que eu iria ser.

Essa adaptaçáo modesta foi muito útil para mim. $\mathrm{Na}$ fase inicial, em que me reciclava para ser um estudante universitário, porque me impelia a começar pelos alicerces, pelo $\mathrm{ABC}$ das ciências sociais. Náo caí na armadilha dos que condenavam os manuais. Tive o bom senso de buscar neles uma base geral - que não nos era dada através dos cursos ecléticos e monográficos, preferidos pela maioria dos mestres - e de deixar em aberto o ponto de chegada, o qual năo sabia qual poderia ser. Ao mesmo tempo, estabelecia uma trégua entre o meu medo de falhar e a intimidaçáo que resultava do alto nível acadêmico dos professores estrangeiros, que criava uma desanimadora barreira psicológica dentro do próprio eixo em que gravitava a nossa aprendizagem. Na fase em que passei a voar com maior autonomia intelectual, porque năo me tornei vítima da passagem, mais ou menos rápida para todos, do deslumbramento à decepção. Os professores estrangeiros, em sua maioria - não em sua totalidade - eram realmente grandes para nós. Vistos na escala de valores de seus próprios países - e nós tínhamos de chegar a ela e absorvê-la - se eles não eram medícres, contavam entre as figuras de segunda ou terceira grandeza. Mesmo as apostilas de um homem tão famoso, atualmente, como Lévi-Strauss, nada tinham de impressionante. Livros elementares, como a pequena introduçáo de Cuvillier ou o breve tratado de Ginsberg, iam muito mais longe. $O$ fato é que não se poderia ler os clássicos, antigos ou recentes - de Montesquieu e Rousseau a Comte, de Marx a Durkheim, Tönnies e Weber, ou de Mannhein, Mauss, Simiand, Cassirer, Dilthey, Giddings a Cooley, Ogburn, Park, Znaniecki, Laski, Sorokin e tantos outros - sem sofrer essa evolução paradoxal, que nos expunha a cruéis reflexóes melancólicas. Além do mais, boa parte do brilho e da significafáo daquele ensino desembocava em um vazio pedagógico. A carência de dinamismos intelectuais universitários nos entregava àquela relaçáo em termos de absolutos: se náo nos dão o melhor e se não vamos, por conseqüência, ser os melhores, de que nos adianta o refinamento de uma cultura européia diletante e decadente ou de uma cultura norte-americana postiça, táo emprestada quanto a 
nossa? Alguns colegas, como Benedito Ferri de Barros e Laerte Ramos de Carvalho, não deixavam de remoer esses percalços, atacando, às vezes aberta e francamente, o puritanismo intelectual que me levava a um aparente ajustamento zarolho. A minha adaptaçáo protetora conduziame em outra direçáo. Eu estava na época da semeadura: qualquer que fosse a grandeza relativa dos meus mestres, eu tinha o que aprender com eles e o que eles ensinavam ou transcendia aos meus limites ou me ajudava a construir o meu ponto de partida. Cabia-me aproveitar a oportunidade. A leitura de Mannheim, em particular, que iniciara com intensidade já nos começos de 1942, convencera-me de que a consćiência crítica, para ser criadora, não precisa ser dissolvente.

\section{(...)}

A questão era ter acesso aos professores fora dos contactos formais das salas de aula. Eu náo sabia como conseguir isso $\mathrm{e}$, o pior, náo era capaz e falar francês ou italiano. Como também não possuía um nome de familia, eu desaparecia no pequeno número, como se estivesse perdido em uma massa enorme de estudantes. No entanto, como tinha decidido concentrar o melhor dos meus esforços nos trabalhos de aproveitamento, foi por aí, inesperadamente, que se abriram as portas para entrevistas pessoais e das casas daqueles professores. Durante 1941, dediquei-me com o maior afinco a dois desses trabalhos. Um, que fora passado pelo professor Paul Hugon, sobre $A$ evolufăo do comércio exterior no Brasil, da Independencia a 1940; e outro, que fora pedido pelo professor Roger Bastide, sobre $O$ folclore em São Paulo. Com o professor Hugon tudo evoluiu naturalmente e com muita rapidez. Ele próprio me chamou e me disse que considerava que eu tinha, ali, o ponto de partida para uma tese de doutoramento. Pôs-se à minha disposiçáo para orientar-me e, ao saber de minhas dificuldades, também me informou que me arranjaria üm emprego mais condizente com minhas aspiraçóes e possibilidades. De fato, ao retornar da França, depois das férias, me chamou de novo. Havia conseguido que eu fosse aceito por Roberto Simonsen, em um grupo de jovens que trabalhava diretamente para ele. Isso me deixou perplexo e me forçou a uma primeira decisão. Parecia-me que, se aceitasse aquele emprego, iria converter-me no que eu pensava ser, na minha ingenuidade, um camelo intelectual, alguém que năo usa a própria inteligência para si, porém a vende para os outros. Recusei polidamente e ficamos muito amigos, sem que o professor Hugon desistisse do plano de doutoramento, que tinha engendrado. Com o professor Bastide os contactos foram mais lentos e, na verdade, provocados por mim. Para um recém-egresso dos quadros mentais da cultura de folk, aquela pesquisa era fascinante. Eu lancei-me a ela com o alvoroço de um primeiro 
amor. A bagagem intelectual era deficiente, pois a professora Lavínia da Costa Vilela se limitara a nos introduzir em alguns conceitos básicos de Sébillot e de Saintyves, Náo obstante, graças às aulas do próprio Bastide, eu já estava lendo Durkheim e Mauss e me sentia capaz de projetar o folclore no meio social interno. Dadas as minhas origens de autodidata, foi-me muito fácil trabalhar uma ampla bibliografia, existente na Biblioteca Municipal, na Biblioteca Central da Faculdade (no que o senhor Raspantini me ajudou muito) e na Biblioteca da Faculdade de Direito. Em função da minha experiência de vida táo recente, sabia onde coligir os dados e como. Por conseguinte, fiz um levantamento e uma análise que estavam acima do que se poderia esperar de um trabalho de aproveitamento e, em particular, de um estudante do primeiro ano. Todavia, depois de um duro esforço, pretendia pelo menos uma compensaçáo psicológica. Ela não veio. A professora Lavínia me deu nove e, como eu insistisse em um debate crítico, adiantou a opinião, com a qual não concordei, de que eu fora longe demais no tratamento sociológico do folclore. Esperei a volta do professor Bastide e exigi dele uma definição: não me importava a nota, queria uma crítica séria do trabalho. Ele ficou surpreso. 'Como, existe uma monografia sobre o folclore de São Paulo? Ela me interessa muito'. Entreguei-lhe o trabalho dias depois. Não se passou muito tempo e ele me convidou a ir à sua casa. Disse-me que estava disposto a corrigir a nota, que ele julgava injusta (o que recusei) e fez comentários preciosos sobre a interpretacáo sociológica dos dados, demonstrando que eu tomara uma pista correta e que ela poderia ser explorada de modo ainda mais amplo. Ao saber das minhas dificuldades, também se ofereceu para conseguir-me um emprego de tipo intelectual. Levou-me a Sérgio Milliet e este teve o bom senso de decidir: se o Florestan começa a trabalhar aqui, na Biblioteca Municipal, ele enterra qualquer carreira que o seu talento lhe possa abrir. Como alternativa, colocou-se à minha disposiçâo para publicar os artigos que quisesse escrever em $O$ Estado de São Paulo. O professor Bastide, porém, não parou aí. Levou o trabalho ao professor Emílio Willems e pediu sua publicaçáo na revista Sociologia. Dias depois, o Dr. Willems me chamou. Ele não tinha como publicar um trabalho tão grande na revista. Mas deu-me instruções para redigir trabalhos menores, que ele publicaria, $\mathrm{e}$ fez uma crítica severa da coleta de dados. Pela primeira vez vi qual era a diferença entre o amador e o profissional, o aprendiz e o mestre; e creio que aproveitei bem a lição, que iria servir de ponto de referência no meu modo de entender e praticar a pesquisa empírica sistemática como sociólogo. No mesmo ano, 1942, saiu o meu primeiro artigo na revista Sociologia. Quanto à colaboração para o Estado (e quase simultaneamente para a Folba da Manbã), só iniciaria no ano seguinte, depois de vencer o temor de enfrentar o grande público. Bastide tornou-se, daí em diante, 
o meu principal professor e um dos meus melhores amigos. Hugon e Willems, por sua vez, dispensavam-me a atençăo que, naquela época, só se dava aos estudantes de talento reconhecido, que desfrutavam uma posiçáo intelectual ambivalente, a meio caminho entre o amigo, o protegido e o futuro colega. Como José, na corte do Faraó, eu tivera o engenho de aformosear o meu destino, agarrando a sorte pelos cabelos.

\section{(...)}

Foi através do ensino e da pesquisa, porém, que completei a minha formaçáo sociológica. Entre 1942 e 1945 fiz vários pequenos levantamentos (como o estudo sobre as manifestaçóes do preconceito de cor em Sorocaba e do culto a Joăo de Camargo; uma análise quantitativa da competiçăo entre profissionais liberais em São Paulo, com base em identificaçóes extraídas das listas telefônicas; uma sondagem, através de questionários, da populaçăo rural de Poá, na qual tive a colaboraçăo de Oswaldo Elias Xidieh; certa participaçáo na pesquisa do Dr. Willems, sobre Cunha, na qual me encarreguei de estudar determinados aspectos do folclore ou da vida sexual da comunidade e ajudei na coleta de dados antropométricos; uma exploração dos dados quinhentistas sobre os contactos dos Tupi com os brancos, em Sáo Paulo, uma pesquisa que deveria fazer com o Dr. Donald Pierson mas que interrompemos de modo prematuro, um balanço crítico das contribuiçóes que Gabriel Soares e Hans Staden poderiam dar para o estudo da vida social dos Tupinambá e seus contactos com os brancos); e em 1944 iniciara, graças ao empenho e à colaboraçáo desinteressada de Jamil Safady, uma pesquisa sobre a aculturação de sírios e libaneses em São Paulo (na qual trabalhei quase quatro anos e que foi posta de lado por falta de recursos materiais, além de outros motivos). Em suma, fui treinado de várias maneiras para ser um pesquisador. Essa experiência extensiva, no entanto, não diz tudo. A pesquisa de 1941 (complementada parcialmente em 1944), sobre o folclore, e o levantamento sistemático dos dados conhecidos sobre os Tupinambá (iniciado em 1945 e completado em 1946) constituem um marco na minha preparaçáo sociológica. Quanto ao folclore, retomei por várias vezes os materiais coligidos para submetê-los a uma análise em profundidade. $O$ trabalho que teve mais importância para mim foi o que escrevi sobre as trocinbas do Bom Retiro. Pela primeira vez, via-me enfrentando as tarefas de materializar e de reconstruir as bases sóciodinâmicas da vida em grupo. Não só tive oportunidade de passar do plano abstrato para o plano concreto no uso de conceitos, hipóteses e teorias; precisei formular, por minha conta, as perguntas que o sociologo tem de responder quando examina, empiricamente, a estrutura e as funcóes do grupo social, nos vários níveis da vida humana. Por isso, esse pequeno trabalho representou, para mim, uma passagem da iniciafáto 
didatica para a iniciafáo cientlfica, e eu lhe devo, em termos de aprendizagem, muito mais do que fiquei devendo aos cursos que freqüentara anteriormente. Formei, entáo, o meu próprio tirocínio sobre a análise de dados empíricos; e fiquei sabendo por que a reconstruçáo empírica năo basta à explicaçáo sociológica: os fatos náo falam por si mesmos. É preciso interrogá-los e, para isso, é indispensável algum domínio do quadro teórico envolvido. O velho leitor de Simiand recolocou-se a exigência fundamental - nem teorias sem fatos nem fatos sem teorias - à luz de uma perspectiva nova, nascida de uma pesquisa precária, é certo, mas muito rica de consequiência para o meu amadurecimento como sociólogo-pesquisador.

Não obstante, foi através do estudo sobre os Tupinambá que me senti forçado a ir muito mais longe. A pesquisa năo só não era uma experiência improvisada, apesar de ser o meu primeiro contato mais íntimo com a reconstruçáo histórica. Os Tupinambá me colocavam, como diria Mauss, diante da necessidade de explicar uma civilizaçáo, como o demonstra $A$ organizafáo social dos Tupinambd. Fui obrigado a mobilizar todos os conhecimentos que pudera acumular sobre técnicas empíricas e lógicas de pesquisa. E tive de alargar o meu conbecimento das sociedades primitivas, para poder entender, descrever e explicar as estruturas e os dinamismos da sociedade tribal. Eu me via questionando, ao mesmo tempo: os cronistas e as suas contribuições empíricas para o estudo sistemático dos Tupinambá; a minha capacidade (e limitaçóes) como investigador; as técnicas de formação de inferência e de construçáo de teoria que podia utilizar; as teorias sociológicas e antropológicas sobre a estrutura social e a organizaçáo social; os quadros sociais da conquista, da escravidão das populaçōes indígenas, da expropriação da terra pelos portugueses e da dizimaçăo dos nativos. Na verdade, se já era uma lagarta, quando principiei a investigaçăo, ao terminá-la converterame em uma borboleta. Descobri que nenhum sociólogo é capaz de realizar o seu ofício antes de percorrer todas as fases de um projeto de investigaçáo completo, no qual transite do levantamento dos dados à sua crítica e à sua análise e, em seguida, ao tratamento interpretativo propriamente dito. Os que repudiam o estudo de comunidade ou o estudo de casso com tanta obstinaçáo, ignoram esse lado pedagógico do treinamento científico pela pesquisa empírica sistemática. Um investigador isolado dificilmente pode ir mais longe do que eu tentara ir, embora ficasse com a frustraçáo de descobrir que nunca se chega, na verdade, ao relato de todos os conhecimentos acumulados e verificados. Com essa pesquisa, náo só obtive o grau de mestre em ciências sociais: alcancei a estatura de um artesão que domina e ama o seu mister, porque sabe como deve praticá-lo e para o que ele serve. Ela ajudou-me a modificar a minha 
concepção da sociologia e da natureza ou alcance da explicaçáo sociológica. Podia encadear-me a uma tradiçáo de pensamento científico de um modo mais crítico, que me levaria a recusar a reconstrução empírica como o alvo final e a ver na contribuiçáo teórica o objetivo central da investigaçáo sociológica. Por aí, penetrei na esfera dos problemas da indução na sociologia com uma bagagem mais sólida, que me permitia indagar como se passa dos fatos às teorias, e me obrigava a exigir do sociólogo algo mais do que uma descrifáo bem feita da realidade.

Nem por isso a experiência em nível de ensino teve importância menor para mim. Ao contrário, a sala de aula logo se tornaria, em termos de formaçáo e de amadurecimento intelectuais, uma espécie de equivalente do laboratório. No começo, por insegurança e por falta de tempo (a cadeira de Sociologia II só foi incorporada ao regime de tempo integral em 1947) negligenciava um tanto a preparação das aulas. Como fazia várias coisas simultaneamente - e com dois empregos! - tendia a reduzir o peso relativo da carga de trabalho didático e explorava mal as potencialidades pedagógicas da relaçáo com o estudante como uma via real do auto-aperfeiçoamento. Aos poucos, porém, a paixão pelas tarefas didáticas cresceu dentro de mim e, especificamente, como parte da complexa situaçáo de aprendizagem que elas engendram, pela qual o professor quase sempre aprende, graças à e através da sala de aula, mais que o próprio estudante. Isso é paradoxal. Mas constitui uma verdade elementar. Como o pesquisador, o professor precisa reduzir o conhecimento acumulado previamente ao que é essencial e, mais que o pesquisador, deve defrontar-se com o dever de expor tal conhecimento de modo claro, conciso e elegante. Por pequeno que seja o potencial agregador do estudante no processo de aprendizagem, o ensino, em si mesmo, é instrutivo e criador para o professor, independentemente do prazer de cnsinar ou do que se pode aprender com o estudante. Ao atingir esse patamar, o ensino perdeu, para mim, o caráter de um fardo e a relação com os estudantes passou a ser altamente provocativa e estimulante para o meu progresso teórico como sociólogo. Na verdade, antes que se fizessem sentir as avaliaçōes de meus pequenos escritos e livros, foram os estudantes que descobriram e reconheceram o meu valor, oferecendo-me uma base psicológica de auto-afirmação e de segurança relativa fundamental para a eliminaçăo de velhas cicatrizes, ambivalências e hesitaçóes. Os estudantes sempre foram generosos comigo e sempre responderam construtivamente ao que eu pretendia fazer, praticamente desde o início da minha carreira docente, ajudando-me a moldar-me segundo uma imagem do professor que transcendia às possibilidades da tradicional escola superior brasileira.

A fase inicial foi dura para mim e para os estudantes. Como todo 
professor jovem, eu não estava preparado para ensinar em cursos de graduaçáo. Esses cursos, em nível introdutório, requerem professores de longo tirocínio, maduros no trato com a matéria e com o ensino. Ora, eu estava também reaprendendo. Em consequiência, excetuando-se um curso semestral, de comentário crítico de As regras do método sociológico, que dei em 1945, professei cursos inevitavelmente indigestos, nos quais os meus pontos de chegada se convertiam nos pontos de partida dos estudantes. Eu tendia a levar minha fermentação mental para a sala de aula e não poupava ninguém. Não pretendia impor-me acima do aprendiz de sociólogo. Não obstante, as indagaçóes que me absorviam eram descarregadas sobre os estudantes sem piedade, com um impacto devastador. Se eles aprendiam muito a respeito das correntes sociológicas mais importantes, em compensação tinham de aceitar um tremendo e tempestuoso desgaste intelectual, do qual eu não me poupava e tampouco tinha a intençáo de poupá-los. Muitos desistiam dos cursos ou achavam a sociologia muito difícil. Os que ficavam, porém, rompiam comigo o terreno a desbravar e acabavam sentindo a verdadeira sedução que o pensamento sociológico é capaz de provocar nas mentes criadoras. Vários deles seriam, mais tarde, sociólogos competentes e meus colegas. Não sei o que pensam, hoje, do meu fanatismo cientifico e do meu sociologismo inveterado nem como avaliam a precariedade das rotas de aprendizagem que percorremos juntos, com tanto ardor intelectual. Mas acredito que esse período não seria tão fecundo, para mim, se não tivesse congestionado as aulas e feito os alunos arrostarem, em minha companhia, os altos e baixos dos debates sociológicos em que os envolvi.

Aos poucos, esse tipo de ensino conturbado e perturbado foi desaparecendo: ao digerir as minhas leituras e ao compreender melhor as minhas próprias funçóes docentes tornei-me um professor mais experiente e competente. Entáo, já podia encarar o estudante e o ensino da sociologia de outra maneira, superando o comensalismo predatório da fase inicial. O meu campo de escolhas se ampliava e eu encetava uma nova experiência, pela qual iria associar a exploração de vários campos da sociologia às minhas tarefas didáticas. Graças ao crescimento e ao aperfeiçoamento do próprio Departamento de Sociologia e Antropologia, tornava-se possível entender, ainda que rudimentarmente, as fronteiras do trabalho produtivo e inventivo da área das leituras e da pesquisa para a esfera do ensino. Como os cursos de introduçáo se tornaram formativos, lecioná-los significava adquirir um domínio maior sobre os conhecimentos básicos da sociologia. Ao mesmo tempo, os cursos monográficos - determinados acima das preferências individuais dos professores - surgiam como uma vantajosa alternativa de auto-realizaçáo profissional. 
Tudo isso indica que, no início da década de 50, o período de formação chegava ao fim e, simultaneamente, revelava os seus frutos maduros. Eu já estava terminando a redação de $A$ funfão social da guerra na sociedade Tupinambá e dispunha de condiçóes não só para colaborar com Bastide em uma pesquisa táo complexa como a que fizemos sobre o negro em Sáo Paulo, mas para ser encarregado do planejamento da mesma e da redaçáo do projeto de investigaçáo. Estávamos em uma nova era, para mim, e as minhas responsabilidades sofriam uma transformação rápida, quantitativa e qualitativa. Graças à transferência para a cadeira de Sociologia I (oficializada em 1952) e, em seguida, ao contrato como professor em substituiçăo a Roger Bastide, eu me via diante da oportunidade de contar com uma posiçáo institucional para pôr em prática as concepçóes que formara a respeito do ensino da sociologia e da investigaçáo sociológica. Converti essa cadeira em um pião para atingir fins que são inacessíveis ao professor e ao investigador isolados. Como D'Artagnan, ao chegar a Paris, eu estava disposto a lutar com qualquer um que dissesse que nós não somos capazes de impor a nossa marca à sociologia. Ao antigo símbolo do made in France eu pretendia opor o feito no Brasil. Náo estava em busca de uma estreita sociologia brasileira. Pretendia, isso sim, implantar e firmar padróes de trabalho que nos permitissem alcançar o nosso modo de pensar sociologicamente e a nossa contribuiçáo à sociologia. Os fatos iriam mostrar que isso era possível, que eu não forjara uma pura utopia profissional. Pois durante quase quinze anos (de 1955 a 1969) - em que fiquei à testa da cadeira de Sociologia I - eu e meus colaboradores demonstramos, através de intensa e fecunda atividade intelectual, que essa possibilidade pode ser comprovada na prática. As dificuldades inerentes a uma universidade estática, à ausência de tradiçäo cientifica, à escassez dos recursos materiais, à extrema dependência cultural do país e às interferências reacionárias do pensamento conservador não impediram que realizássemos programas altamente complexos de ensino e de pesquisas, que estabeleceram a nossa reputação científica, nos círculos acadêmicos e fora deles. O nosso esforço não pode nem deve ser isolado do que fizeram outros sociólogos brasileiros. Contudo, ele foi encarado, aqui e no exterior, como um índice de autonomia intelectual e de capacidade criadora independente. $O$ que fomentou o mito da escola paulista de sociologia e nos conferiu um prestígio que sobreviveu ao expurgo que sofremos".

\section{Notas}

1 Quanto aos exames de seleçăo para o pré, muito concorridos (talvez a proporção fosse 
de dez candidatos para uma vaga), consegui aprovaçăo em segundo lugar. Com referência aos exames de habilitação para ciências sociais, havia trinta vagas e somente vinte e nove candidatos. Na seleção, porém, só seis foram qualificados (eu era o quinto). Em seguida, mais dois entraram através dos exames de segunda época. Como dois desistiram, o nosso grupo era de seis, acrescido, mais tarde, de uma aluna que se transferira do Rio de Janeiro.

2 Ginásio Riachuelo

Florestan Fermandes é professor emérito do Departamento de Ciências Sociais da Faculdade de Filosofia, Letras e Ciências Humanas da USP. 